\section{Soil $\mathrm{CO}_{2}$ Concentration Effects on Creeping Bentgrass Grown under Various Soil Moisture and Temperature Conditions}

\author{
Ian R. Rodriguez and Lambert B. McCarty ${ }^{1}$ \\ Department of Horticulture, D-136Poole Agriculture Center, Clemson University, \\ Clemson, SC 29634-0319
}

\author{
Joe E. Toler \\ Department of Applied Economics and Statistics, Clemson University, Clemson, \\ SC 29634
}

\author{
Roy B. Dodd \\ Department of Agricultural and Biological Engineering, Clemson University, \\ Clemson, SC, 29634 \\ Additional index words. Agrostis stoloniferous var. palustris, carbohydrates, photosynthesis, \\ respiration, turfgrass
}

\begin{abstract}
Use of creeping bentgrass [Agrostis stoloniferous L. var. palustris (Huds.)] on golf greens has expanded into the hotter, more humid regions of the United States where its quality is often low during summer months. The summer decline in bentgrass quality may be partially attributed to respiration rates exceeding photosynthesis during periods of supraoptimal temperatures and adverse soil conditions, such as excessive $\mathrm{CO}_{2}$ and inadequate $\mathrm{O}_{2}$ levels. The objectives of this study were to examine the effects of high temperature, high soil $\mathrm{CO}_{2}$, and irrigation scheduling on creeping bentgrass growth. A growth chamber study was conducted using ' $\mathrm{A}-1$ ' creeping bentgrass. Treatments included all combinations of three day/night temperature regimes $\left(26.5 / 21{ }^{\circ} \mathrm{C}, 29.5 / 24^{\circ} \mathrm{C}\right.$, and 32/26.5 ${ }^{\circ} \mathrm{C}$ ), three irrigation schedules (field capacity daily, field capacity every two d, and half field capacity daily), and four soil $\mathrm{CO}_{2}$ injection levels $(10 \%, 5 \%, 0.03 \%$, and a noinjection control). Creeping bentgrass shoot and root dry weights and net photosynthetic rates were greater for day/night temperatures $<32 / 26.5^{\circ} \mathrm{C}$. High temperatures $\left(32 / 26.5^{\circ} \mathrm{C}\right)$ and $10 \% \mathrm{CO}$, reduced bentgrass net photosynthesis by $37.5 \mu \mathrm{mol} \mathrm{CO} / \mathrm{m}^{2} / \mathrm{s}$. Shoot and root total nonstructural carbohydrates also were lowest for highest temperature regime. Respiration exceeded gross photosynthesis at 32/26.5 ${ }^{\circ} \mathrm{C}$ when $5 \%$ and $10 \% \mathrm{CO}_{2}$ injection levels were used, indicating a carbon deficit occurred for these conditions. Irrigation volume and frequency did not affect bentgrass growth. High temperatures combined with high soil $\mathrm{CO}_{2}$ levels produced poorest turf quality.
\end{abstract}

Creeping bentgrass [Agrostis stoloniferous L. var.palustris (Huds.)] is the cool-season grass most widely used on golf greens (Beard, 1982). Preference for the superior putting surface of bentgrass has led to its use in the hotter, more humid regions of the United States where its quality often declines during summer months. This condition is referred to as summer bentgrass decline (McCarty, 2005).

Factors contributing to summer decline of bentgrass include poor soil aeration, excessive or deficient soil water, high relative humidity, high temperatures, and soil-borne disease organisms. Supraoptimal temperatures cause root loss, reduced shoot and tiller growth, and reduced shoot density in creeping bentgrass (Dipaola and Beard, 1992; Huang et al., 1998a, 1998b; Krans and Johnson, 1974). This growth decline is attributed to a reduction in photosynthesis and an increase in respiration at temperatures above $30^{\circ} \mathrm{C}$ (Huang

Received for publication 9 Aug. 2004. Accepted for publication 12 Oct. 2004. Technical Contribution no. 5047 of the Clemson Univ. Experiment Station, Clemson, SC

${ }^{1}$ To whom reprint requests should be sent;e-mail bmccrty@clemson.edu. et al., 1998a; Huang and Gao, 2000). Imbalance between photosynthesis and respiration leads to a reduction in carbohydrate accumulation (Huang et al., 1998a; Huang and Gao, 2000) and lower carbohydrate availability may be responsible for reduction of growth (Baker and Jung, 1968; Dipaola and Beard, 1992; Liu and Huang, 2000; Watschke et al., 1970, 1972).

The composition of the soil atmosphere may also affect bentgrass survival. During hot summer months, soil $\mathrm{O}_{2}$ levels can become depleted due to increased root and microbial respiration (Waddington and Baker, 1964; Williamson, 1964). Creeping bentgrass root viability and dry matter are reduced under high air $\left(35^{\circ} \mathrm{C}\right)$ and soil $\left(25^{\circ} \mathrm{C}\right)$ temperatures and limited soil $\mathrm{O}_{2}$ concentration $\left(2.0 \times 10^{-7} \mathrm{~g} \cdot \mathrm{cm}^{-2} \cdot \mathrm{min}^{-1}\right)$ (Huang et al., 1998a). Saturated or anoxic soil conditions limit bentgrass root length (Huang, 1997). Although some plants are able to develop a dense, shallow root system to take advantage of more favorable $\mathrm{O}_{2}$ conditions (Glinski and Stepniewski, 1985), roots of most crop plants are unable to survive at $\mathrm{O}_{2}$ levels $<2 \%$ to $5 \%$ with optimum levels between $5 \%$ and $15 \%$ (Barden et al., 1987). Minimum $\mathrm{O}_{2}$ levels for maintaining creeping bentgrass quality have not been established.

Due to root and microbial respiration, soil $\mathrm{CO}_{2}$ can reach levels of ten to one hundred times greater than in atmospheric air (Bremner and Blackmer, 1982; Hillel, 1980). Elevated $\mathrm{CO}_{2}$ levels may adversely affect roots by decreasing root cytoplasmic $\mathrm{pH}$ and interfering with water and nutrient uptake (Chang and Loomis, 1945). Soil $\mathrm{CO}_{2}$ levels $\geq 2.5 \%$ reduced creeping bentgrass root dry weight by $40 \%$ and root length by 2 to $3 \mathrm{~cm}$ when grown under greenhouse conditions (Bunnell et al., 2002).

Although golf greens grown on sand mixes have lower $\mathrm{CO}_{2}$ levels than unamended soils (Kavanagh and Jelley, 1980), thatch, surface compaction, algae, and a dense turf may decrease gas diffusion. Golf greens are typically watered frequently during summer months due to high evapotranspiration rates. Jordan (1998) reported irrigation of bentgrass greens increased soil $\mathrm{CO}_{2}$ concentrations from $0.8 \%$ to $2.8 \%$ and attributed the increase to limited gas exchange due to soil water.

Forcing air into or out of a U.S. Golf Association (USGA) green rootzone (USGA Green Section Staff, 1960) through subsurface drain lines may improve soil conditions for bentgrass growth. Preliminary studies by Dodd et al. (1999) indicate increased soil $\mathrm{O}_{2}$ and decreased $\mathrm{CO}_{2}$ levels with both pressure and vacuum induced subsurface air movement treatments in a USGA bentgrass green. No root or shoot growth differences were observed. Similar experiments using vacuum or pressure modes conducted on USGA bentgrass greens have reported $50 \%$ to $80 \%$ reductions in soil $\mathrm{CO}_{2}$ (Bunnell et al., 2004) or soil gases remaining close to atmospheric levels (Bigelow et al., 2001). These studies reported little effect on bentgrass growth or rooting, however.

The objective of this study was to examine the effects of high soil $\mathrm{CO}_{2}$ concentrations on creeping bentgrass grown under various soil moisture and temperature conditions.

\section{Materials and Methods}

A growth chamber study was conducted in 2001 and 2002 to examine whether temperature and soil moisture influence the tolerance of bentgrass to various soil $\mathrm{CO}_{2}$ levels. Growth cells were constructed to simulate aUSGAgreen in growth chambers. Plexiglass tubes $30 \mathrm{~cm}$ tall with a $5-\mathrm{cm}$ diameter were used as growth cells. Cell bottoms were sealed with fabricated plastic caps and epoxy. Each cap was fitted with air-tight, quick-disconnect fittings for attaching 0.95-cm-diameter tubing. The bottom of each cell was filled with 6-12 mm diameter gravel to a depth of $5 \mathrm{~cm}$. Fifteen $\mathrm{cm}$ of USGA specified 85 sand : 15 peat soil mix was placed on top of the gravel. Plugs of 'A-1' creeping bentgrass ( $10 \mathrm{~cm}$ height $\times 5 \mathrm{~cm}$ diameter) were harvested from an experimental USGA green in Clemson, S.C., and placed on top of the soil mix in each cell. Newly planted growth cells were saturated with water and allowed to drain freely for $24 \mathrm{~h}$. After draining, the outer walls of each cell were wrapped in aluminum foil to prevent light entry into the root zone, and the weight of each cell 
at field capacity was determined.

Completed growth cells were then placed in growth chambers and allowed to acclimate to the light and temperature regime of the chamber for a period of $14 \mathrm{~d}$ before soil gas injections were initiated. During this $14 \mathrm{~d}$ acclimation, foliage was maintained at a height of $4 \mathrm{~mm}$. Cells were watered every other day during this period by weighing each cell and applying enough water to bring the growth cell back to field capacity. Cells were fertilized using a 10-10-10 solution at an $\mathrm{N}$ rate of $12 \mathrm{~kg} \cdot \mathrm{ha}^{-1}$ beginning the day before treatments were initiated and continuing once every $14 \mathrm{~d}$.

PVC lines $3 \mathrm{~cm}$ in diameter were used for removing water that drained from the cells and for supplying soil gases to the cells. The PVC lines were constructed with 30-cm deep p-traps that allowed water to drain from the cells but did not allow air to escape or enter, and the lines were connected to solenoid valves that regulated the timing and duration of gas injections from pressurized tanks. Latex balloons were fitted over the open end of each p-trap to provide additional pressure and prevent drained water from blowing out. Soil gases were injected into the cells through $0.95-\mathrm{cm}$ diameter tubes attached to the PVC lines. Based on preliminary studies, it was determined that soil gases could be maintained in the cells at assigned levels by injecting gas mixtures once every $20 \mathrm{~min}$ for a duration of $1 \mathrm{~min}$.

The $3 \times 3 \times 4$ factorial experiment provided three replications per treatment combination and was conducted in a completely randomized split-plot design. Treatments included all combinations of three temperature regimes, three irrigation schedules, and four soil gas injection levels. The temperature regimes were randomly assigned to the growth chambers (whole plots) that contained growth cells for all combinations of the two sub-plot factors, irrigation and soil gases. Temperature regimes consisted of the day/night temperatures $26.5 / 21{ }^{\circ} \mathrm{C}, 29.5 / 24$ ${ }^{\circ} \mathrm{C}$, and $32 / 26.5^{\circ} \mathrm{C}$ to simulate typical summer climates in the southern region of the U.S. Irrigation regimes consisted of weighing each cell and adding appropriate amounts of water to either

Table 1. Gas composition of soil injections used on creeping bentgrass.

\begin{tabular}{lcrc}
\hline & \multicolumn{3}{c}{ Gas composition (\%) } \\
\cline { 2 - 4 } Soil injection & $\mathrm{O}_{2}$ & $\mathrm{CO}_{2}$ & $\mathrm{~N}_{2}$ \\
\hline High $\mathrm{CO}_{2}$ & 10.00 & 10.00 & 80.00 \\
Low $\mathrm{CO}_{2}$ & 15.00 & 5.00 & 80.00 \\
Air & 20.94 & 0.03 & 78.09 \\
Control & --- & --- & --- \\
\hline
\end{tabular}

bring the cell to field capacity daily, every $2 \mathrm{~d}$, or one-halffield capacity daily. The four soil gas injection levels are described in Table 1.

Cells were subjected to the treatments for 6 weeks. Light intensity was $550 \mu \mathrm{mol} \cdot \mathrm{m}^{-2} \cdot \mathrm{s}^{-1}$ at the turf surface. Turf was mowed every $2 \mathrm{~d}$ at a height of $4 \mathrm{~mm}$ throughout the experiment. Data was collected on net photosynthesis and dark respiration, shoot and root dry weights, and shoot and root total nonstructural carbohydrate (TNC) concentrations.

Net photosynthesis and dark respiration were measured after 6 weeks of treatment using an open gas exchange system as described in Miller et al. (1996). Cell drainage and gas-injection openings were plugged during sampling. A gas exchange chamber was constructed to fit directly on top of a growth cell.Aclear plexiglass growth cell tube was cut to a height of $15 \mathrm{~cm}$. The top was covered with a clear disposable petri dish and sealed with clear silicone adhesive. The chamber was sealed atop each cell during measurements using a clear plastic end cap with the bottom removed. A $0.6-\mathrm{cm}$-diameter inlet was drilled at a height of $1.5 \mathrm{~cm}$ above the open end of the chamber. An aquarium-type electric air pump with a 0.6-cm-diameter tube was used to provide positive air flow to the chamber inlet at $0.0183 \mathrm{~L} \cdot \mathrm{s}^{-1}$. One $0.03-\mathrm{cm}$-diameter outlet was drilled $1 \mathrm{~cm}$ from the top of the chamber for a gas sampling tube. Laminar flow from inlet to outlet was prevented by using a piece of tape as a deflector at the inlet. Chamber air samples were taken by inserting $2 \mathrm{~cm}$ of a 0.02-diameter air sampling tube through the chamber outlet. Change in $\mathrm{CO}_{2}$ concentration was measured using a portable, infrared gas analyzer (CIRAS-1; PP Systems, Haverhill, Mass.) after 2 min to allow the chamber to reach equilibrium. Net photosynthesis measurements were taken between 1200 and 1400 HR and dark respiration measurements were taken between 0000 and $0200 \mathrm{HR}$.

Upon completion of the experiment, plant carbohydrates were analyzed (Westhafer et al., 1982) by initially dismantling each experimental cell to partition plant biomass into shoots and roots. Shoots and roots were washed free of soil, flash-frozen by immersing in liquid $\mathrm{N}_{2}$, and freeze-dried for $6 \mathrm{~d}$. Root and shoot dry weights were recorded, and samples were prepared for carbohydrate analysis by grinding in a cyclone mill (Udy Sample Mill; Udy Corp., Fort Collins, Colo.) to pass through a 1-mm screen. Shoot and root tissue carbohydrates were extracted following grinding. Shoot or root tissue $(50 \mathrm{mg})$ was placed into glass test tubes and rehydrated by adding $100 \mu \mathrm{L}$ of $80 \%$ ethanol. Two $\mathrm{mL}$ of $0.1 \mathrm{M}$ sodium acetate buffer ( $\mathrm{pH} 4.5$ ) was pipetted into each tube, vortexed, stoppered, and incubated for $1 \mathrm{~h}$ in a $100{ }^{\circ} \mathrm{C}$ water bath. Following removal, samples were vortexed, allowed to cool for $1 \mathrm{~h}$, and placed back into the $100{ }^{\circ} \mathrm{C}$ bath for $1 \mathrm{~h}$ after which samples were cooled to $20^{\circ} \mathrm{C}$. Invertase $(1 \mathrm{~mL})$ (Sigma, I-4504, 5 units $/ \mathrm{mL}$ in $0.1 \mathrm{M}$ acetate buffer at $\mathrm{pH} 4.5$ ) was added to each tube to break sucrose down into glucose followed by $1 \mathrm{~mL}$ of Rhizital amyloglucosidase preparation (A-7255; Sigma, 50 units $/ \mathrm{mL}$ in $0.1 \mathrm{M}$ acetate buffer). Samples were vortexed, stoppered, and incubated at $40^{\circ} \mathrm{C}$ for $48 \mathrm{~h}$ in a water bath with periodic vortexing and then stored at $3{ }^{\circ} \mathrm{C}$. Enzyme blanks were included.

Samples were analyzed for TNC using a modification of Nelson's Assay (Nelson, 1944; Somogyi, 1945). Standards of 0.0 to $0.7 \mu \mathrm{mol}$ glucose $/ 100 \mu \mathrm{L} \mathrm{H}_{2} \mathrm{O}$ were used to prepare a standard curve for use with the shoot and root carbohydrate extracts. Aliquots $(25 \mu \mathrm{L})$ of the root and shoot sample extracts were pipetted into test tubes. After $1 \mathrm{~mL}$ of copper reagent was added to each tube, samples were gently shaken and heated in a $100{ }^{\circ} \mathrm{C}$ water bath for 20 min. Samples were removed, lightly shaken, and allowed to cool in a room-temperature water bath for $5 \mathrm{~min}$. Samples were again shaken before adding $0.5 \mathrm{~mL}$ of arsenomolybdate reagent and mixing. Absorbance measurements were taken at $520 \mathrm{~nm}$ zeroed on a $0.0 \mu \mathrm{mol} / 100 \mu \mathrm{L}$ glucose standard using a Beckman DU-64 spectrophotometer (Beckman Instrument Inc., Fullerton, Calif.). The standard curve was used to determine the TNC of experimental samples.

Statistical analyses were performed using the SAS General Linear Models procedure (SAS Institute, 1987). Analyses of variance were conducted to evaluate main and interaction effects of the three treatment factors, and mean separation was performed using Fisher's LSD with $\alpha=0.05$.

\section{Results and Discussion}

Creeping bentgrass root dry weights were not affected by temperature, moisture, or soil $\mathrm{CO}_{2}$ injection levels; however shoot dry weight differences due to temperature regimes were detected (Table 2). Mean shoot dry weights were $65 \%$ greater for $29.5 / 24{ }^{\circ} \mathrm{C}$ and $48 \%$ greater for $26.5 / 21{ }^{\circ} \mathrm{C}$ than for the $32 / 26.5^{\circ} \mathrm{C}$ day/night temperatures (Table 3 ). Based on previous research (Krans and Johnson, 1974; Dipaola and Beard, 1992; Huang et al., 1998a,

Table 2. Main and interaction effects of temperature, soil $\mathrm{CO}_{2}$, and soil moisture on creeping bentgrass shoot and root dry weights, total nonstructural carbohydrates (TNC) in shoots and roots, net photosynthesis, and dark respiration.

\begin{tabular}{|c|c|c|c|c|c|c|c|}
\hline \multirow[b]{2}{*}{ Source of variation } & \multirow[b]{2}{*}{$\mathrm{df}$} & \multicolumn{6}{|c|}{ Mean square } \\
\hline & & $\begin{array}{l}\text { Shoot } \\
\text { dry wt }\end{array}$ & $\begin{array}{l}\text { Root } \\
\text { dry wt }\end{array}$ & $\begin{array}{l}\text { Shoot } \\
\text { TNC }\end{array}$ & $\begin{array}{l}\text { Root } \\
\text { TNC }\end{array}$ & $\begin{array}{c}\text { Net } \\
\text { photosynthesis }\end{array}$ & $\begin{array}{c}\text { Dark } \\
\text { respiration }\end{array}$ \\
\hline Temperature (T) & 2 & $3.89^{* * *}$ & 3.91 & $6991.6^{*}$ & $1529.2^{*}$ & $8362.0^{* k}$ & 438.9 \\
\hline $\mathrm{CO}_{2}$ & 3 & 0.20 & 0.28 & 503.3 & 5.6 & $1107.4^{* *}$ & $1258.2^{*}$ \\
\hline $\mathrm{T} \times \mathrm{CO}_{2}$ & 6 & 0.14 & 0.43 & 350.3 & 8.3 & $877.1^{\text {** }}$ & 137.1 \\
\hline Moisture (M) & 2 & 0.12 & 0.32 & 19.3 & 35.1 & 3.8 & 34.0 \\
\hline $\mathrm{T} \times \mathrm{M}$ & 4 & 0.08 & 0.39 & 98.9 & 16.0 & 70.1 & 51.6 \\
\hline $\mathrm{CO}_{2} \times \mathrm{M}$ & 6 & 0.02 & 0.23 & 59.2 & 30.3 & 66.4 & 27.9 \\
\hline $\mathrm{T} \times \mathrm{CO}_{2} \times \mathrm{M}$ & 12 & 0.14 & 0.41 & 78.8 & 0.1 & 58.2 & 27.6 \\
\hline
\end{tabular}

**** Significant at $P<0.05$ or 0.01 , respectively. 
Table 3. Effect of day/night temperature regimes and soil on creeping bentgrass shoot dry weights and total nonstructural carbohydrates (TNC) in shoots and roots.

\begin{tabular}{lccc}
\hline $\begin{array}{l}\text { Day/night } \\
\text { temp }\end{array}$ & $\begin{array}{c}\text { Shoot } \\
\text { dry wt }\end{array}$ & \multicolumn{2}{c}{ TNC $\left(\mathrm{mg} \cdot \mathrm{g}^{-1}\right)$} \\
\cline { 3 - 4 }${ }^{\circ} \mathrm{C}$ & $(\mathrm{g})$ & Shoot & Root \\
\hline $26.5 / 21$ & 1.14 & 57.0 & 32.3 \\
$29.5 / 24$ & 1.02 & 70.5 & 31.0 \\
$32 / 26.5$ & 0.69 & 51.3 & 23.8 \\
LSD $_{(0.05)}$ & 0.217 & 12.87 & 6.49 \\
\hline
\end{tabular}

1998b), shoot dry weights were expected to be lowest for $32 / 26.5^{\circ} \mathrm{C}$ due to decreased carbon assimilation reported for bentgrass at temperatures above $30^{\circ} \mathrm{C}$.

Bentgrass shoot and root TNC contents were affected by day/night temperature regimes but not by soil $\mathrm{CO}_{2}$ or moisture levels (Table 2). Shoot TNC was greater for the $29.5 / 24^{\circ} \mathrm{C}$ temperature regime $\left(70.5 \mathrm{mg} \cdot \mathrm{g}^{-1}\right)$ than for $26.5 / 21$ ${ }^{\circ} \mathrm{C}\left(57.0 \mathrm{mg} \cdot \mathrm{g}^{-1}\right)$ or $32.0 / 26.5^{\circ} \mathrm{C}\left(51.3 \mathrm{mg} \cdot \mathrm{g}^{-1}\right)$ (Table 3), while root TNC was greater for $26.5 / 21$ ${ }^{\circ} \mathrm{C}\left(32.3 \mathrm{mg} \cdot \mathrm{g}^{-1}\right)$ and $29.5 / 24{ }^{\circ} \mathrm{C}\left(31.0 \mathrm{mg} \cdot \mathrm{g}^{-1}\right)$ than for $32 / 26.5^{\circ} \mathrm{C}\left(23.8 \mathrm{mg} \cdot \mathrm{g}^{-1}\right)$. Shoot and root TNC contents were expected to be highest for the lowest temperature regime based on previous research (Liu and Huang, 2000).

Interaction between temperature regimes and soil $\mathrm{CO}_{2}$ injection levels was detected for net photosynthesis (Table 2). Net photosynthesis was greater for the $29.5 / 24^{\circ} \mathrm{C}$ day/night temperature regime than for $32 / 26.5^{\circ} \mathrm{C}$ at all soil $\mathrm{CO}_{2}$ levels except $0.03 \%$ (Table 4 ). Net photosynthesis was unaffected by soil $\mathrm{CO}_{2}$ injection levels when the $26.5 / 21^{\circ} \mathrm{C}$ or $29.5 / 24$ ${ }^{\circ} \mathrm{C}$ temperature regimes were used and averaged 10.8 and $18.5 \mu \mathrm{mol} \mathrm{CO} / \mathrm{m}^{2} / \mathrm{s}$, respectively. However, significant differences among soil $\mathrm{CO}_{2}$ injection levels occurred for the $32 / 26.5$ ${ }^{\circ} \mathrm{C}$ temperature regime, and net photosynthesis generally declined as soil $\mathrm{CO}_{2}$ increased. Net photosynthesis was negative for $5 \%$ and $10 \% \mathrm{CO}_{2}\left(-2.69\right.$ and $-20.21 \mu \mathrm{mol} \mathrm{CO} / \mathrm{m}^{2} / \mathrm{s}$, respectively), indicating respiration exceeded photosynthesis for these soil $\mathrm{CO}_{2}$ levels under heat stress conditions.

Similar results were found by Xu and Huang (2000a, 2000b) with negative bentgrass photosynthetic rates after extended ( $>40 \mathrm{~d}$ ) exposure to $35^{\circ} \mathrm{C}$. They also reported that reductions in net photosynthesis from increased temperature were amplified by high soil $\mathrm{CO}_{2}$ concentrations. Chang and Loomis (1945) inferred that the effect of high soil $\mathrm{CO}_{2}$ levels on photosynthesis may be due to interference with nutrient uptake. Williamson (1964) reported that a reduction in soil $\mathrm{O}_{2}$ can decrease nutrient uptake. Lower soil $\mathrm{O}_{2}$ levels that occur with increased soil $\mathrm{CO}_{2}$ in a field setting were simulated by the gas injection levels in this study. High soil $\mathrm{CO}_{2}$ or low soil $\mathrm{O}_{2}$ levels could reduce photosynthesis capacity by limiting reactions occurring in the chloroplasts due to limited nutrient resources.

Dark respiration was affected by soil $\mathrm{CO}_{2}$ injection levels (Table 2) and generally increased as $\mathrm{CO}_{2}$ increased(Table 4). Dark respiration was greatest $\left(22.20 \mu \mathrm{mol} \mathrm{CO} / \mathrm{m}^{2} \mathrm{~s}\right)$ for $10 \% \mathrm{CO}_{2}$, while $0.03 \% \mathrm{CO}_{2}$ and the control had lowest dark respiration rates (11.32 and $13.32 \mu \mathrm{mol}$ $\mathrm{CO}_{2} / \mathrm{m}^{2} \mathrm{~s}$, respectively). Negative net photo-
Table 4. Effect of day/night temperature regimes and soil $\mathrm{CO}_{2}$ levels on creeping bentgrass net photosynthesis and effect of soil $\mathrm{CO}_{2}$ levels on creeping bentgrass dark respiration.

\begin{tabular}{|c|c|c|c|c|}
\hline \multirow{3}{*}{$\begin{array}{l}\text { Soil } \mathrm{CO}_{2} \\
\text { injection } \\
(\%)\end{array}$} & \multicolumn{3}{|c|}{$\begin{array}{l}\text { Net photosynthesis } \\
\left(\mu \mathrm{mol} \mathrm{CO} / \mathrm{m}^{2} / \mathrm{s}\right)\end{array}$} & Dark \\
\hline & \multicolumn{3}{|c|}{ Day/night temp regime } & respiration \\
\hline & $26.5 / 21^{\circ} \mathrm{C}$ & $29.5 / 24^{\circ} \mathrm{C}$ & $32 / 26.5^{\circ} \mathrm{C}$ & $\left(\mu \mathrm{mol} \mathrm{CO}_{2} / \mathrm{m}^{2} / \mathrm{s}\right)$ \\
\hline 10.0 & 9.8 & 17.3 & -20.2 & 22.2 \\
\hline 5.0 & 10.6 & 20.6 & -2.7 & 17.6 \\
\hline 0.03 & 12.8 & 16.7 & 7.7 & 11.3 \\
\hline control & 10.2 & 19.4 & 4.2 & 13.3 \\
\hline $\operatorname{LSD}(0.05)^{\mathrm{z}}$ & NS & NS & 9.37 & 5.47 \\
\hline
\end{tabular}

${ }^{2}$ For comparison of temperature regimes within a soil $\mathrm{CO}_{2}$ injection level, $\operatorname{LSD}(0.05)=11.27$.

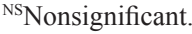

synthesis at high soil $\mathrm{CO}_{2}$ levels for the $32 / 26.5$

${ }^{\circ} \mathrm{C}$ temperature regime reflects respiration rates exceeding gross photosynthesis. This indicates that bentgrass was consuming carbohydrates faster than they were being produced under high temperature stress and high soil $\mathrm{CO}_{2}$ levels, a deficit which eventually leads to decline in turf growth as carbohydrates are depleted. Huang and Gao (2000) reported similar results for creeping bentgrass grown at $34^{\circ} \mathrm{C}$.

Although shoot TNC results were contrary to previous studies, net photosynthesis and dark respiration results were consistent with published findings. Net photosynthetic rates of creeping bentgrass were generally lowest for the $32 / 26.5$ ${ }^{\circ} \mathrm{C}$ day/night temperature regime, and net photosynthesis declined rapidly as soil $\mathrm{CO}_{2}$ increased at this temperature regime. Respiration exceeded gross photosynthesis for $5 \%$ and $10 \% \mathrm{CO}_{2}$ at $32 / 26.5^{\circ} \mathrm{C}$ indicating a carbon deficit caused by high temperature and high soil $\mathrm{CO}_{2}$ levels. Soil moisture levels did not affect creeping bentgrass growth. In summary, this study revealed an imbalance between respiration and photosynthesis of creeping bentgrass at high temperatures and high soil $\mathrm{CO}_{2}$ concentrations. Decline in bentgrass growth and quality are inevitablewhen respiration exceeds photosynthesis. Therefore, identifying means of increasing the photosynthetic capacity of bentgrass by preventing soil $\mathrm{CO}_{2}$ from reaching high concentrations would be invaluable for managing creeping bentgrass under heat stress conditions.

\section{Literature Cited}

Baker, B.S. and G.A. Jung. 1968. Effect of environmental conditions on the growth of fourperennial grasses. I. response to controlled temperature. Agron. J. 60:155-158.

Barden, J.A., R.G. Halfacre, and D.J. Parrish. 1987. Plant Science. McGraw-Hill Book Co., New York.

Beard, J.B. 1982. Turf Management for golf courses. Burgess Publishing, Minneapolis, M.N.

Bigelow, C.A., D.C. Bowman, D.K. Cassel, and T.W. Rufty 2001. Creeping bentgrass response to inorganic soil amendments and mechanically induced subsurface drainage and aeration. Crop Sci. 41:797-805.

Bremner, J.M. and A.M. Blackmer. 1982. Composition of soil atmospheres, p. 873-901. In: A. Klute and A.L. Page (eds.). Methods of soil analysis. part 2. Chemi$\mathrm{cal}$ and microbiological properties. Amer. Soc. Agron. Monogr. 9 (2nd ed.)

Bunnell, B.T., L.B. McCarty, and H.S. Hill. 2004. Soil gas, temperature, matric potential, and creeping bentgrass response to subsurface air movement on a sand-based golf green. HortScience 39:415-419.

Bunnell, B.T., L.B. McCarty, R.B. Dodd, H.S. Hill, and J.J. Camberato. 2002. Creeping bentgrass growth response to elevated soil carbon dioxide. HortScience 37:367-370.

Chang, H.T. and W.E. Loomis. 1945. Effect of carbon dioxide on absorption of water and nutrients by roots. Plant Physiol. 20:221-232.

DiPaola, J.M. and J.B. Beard. 1992. Physiological effects of temperature stress, p. 231-262. In:D.V. Waddingtonetal. (eds.). Turfgrass. ASA-CSSA-SSSA, Madison, Wis.

Dodd, R.B., S.B. Martin, and J.J.Camberato. 1999. Subsurface cooling and aeration. Golf Course Mgt. 67:71-74.

Glinski, J. and W. Stepniewski, 1985. Soil aeration and its role for plants. CRC Press, Boca Raton, Fla.

Hillel, D. 1980. Fundamentals of soil physics. Academic Press, Inc. San Diego, Calif.

Huang, B. 1997. Mechanisms of plant resistance to waterlogging, p. 59-82. In: A.S. Basra and R.K. Basra (eds.). Mechanisms of environmental stress resistance in plants. Harwood Academic Publ., Amsterdam.

Huang, B. and H. Gao. 2000. Growth and carbohydrate metabolism of creeping bentgrass cultivars in response to increasing temperatures. Crop Sci. 40:1115-1120.

Huang, B., X. Liu, and J.D. Fry. 1998a. Shoot physiological responses of two bentgrass cultivars to high temperature and poor soil aeration. Crop Sci. 38:1219-1224.

Huang, B., X. Liu, and J.D. Fry. 1998b. Effects of subirrigation on bentgrass during heat stress in the field. Agron. J. $66: 526-530$.

Jordan, J.E. 1998. Creeping bentgrass performance, water relations, and soil gas response to three irrigation frequencies in a hot-humid climate. MS thesis. Texas A\&M Univ., College Station.

Kavanagh, T. and R.M. Jelley. 1980. Soil atmosphere studied in relation to compaction, p. 181-188. In: R.W. Sheard(ed.) Proc. 4th Intl. Turfrass Res. Conf., Guelph, Canada.

Krans, J.V. and G.V. Johnson. 1974. Some effects of subirrigation on bentgrass during heat stress in the field. Agron. J. 66:526-530.

Liu, X. and B. Huang. 2000. Carbohydrate accumulation in relation to heat stress tolerance in two creeping bentgrass cultivars. J. Amer. Soc. Hort. Sci. 125:442-447.

McCarty, L.B. 2005. Best golf course management practices. 2nd ed. Prentice-hall, Inc., Upper Saddle River, N.J.

Miller, D.P., G.S. Howell, and J.A. Flore. 1996. A wholeplant, open, gas-exchange system for measuring net photosynthesis of potted woody plants. HortScience 31:944-946.

Nelson, N. 1944. A photometric adaptation of the Somogyi method for the determination of glucose. J. Biol. Chem. 153:375-381.

SAS Institute. 1987. SAS user's guide: Statistics. 6th ed. SAS Inst., Inc. Cary, N.C.

Somogyi, N. 1945. A new reagent for the determination of sugars. J. Biol. Chem. 160:61-75.

United States Golf Association Green Section Staff. 1960. Specifications for a method of putting green construction. U.S. Golf Assn. J. Turf Mgt. 13:24-28.

Waddington, D.V. and J.H. Baker. 1964. Influence of soil aeration on the growth and chemical composition of three grass species. Agron. J. 57:255-258.

Watschke, T.L., R.R. Schmidt, and R.E. Blaser. 1970. Responses of somekentucky bluegrass under high temperature and nitrogen fertility. Crop Sci. 10:372-376.

Watschke, T.L., R.R. Schmidt, and R.E. Blaser. 1972. Some metabolic phenomena of kentucky bluegrass under high temperature. Crop Sci. 12:87-90.

Westhafer, M.A., J.T. Law, Jr., and D.T. Duff. 1982. Carbohydrate quantification and relationships with $\mathrm{N}$ nutrition in cool-season turfgrass. Agron. J. 74:270-274.

Williamson, R.E. 1964. The effect of root aeration on plant growth. Soil Sci. Soc. Amer. Proc. 28:86-90.

Xu, Q. andB. Huang. 2000a. Growth and physiological responses of creeping bentgrass to changes in air and soil temperatures. Crop Sci. 40:1363-1368.

Xu, Q. and B. Huang. 2000b. Effects of differential air and soil temperature on carbohydrate metabolism in creeping bentgrass. Crop Sci. 40:1368-1374. 